\title{
Are Endocan Plasma Levels Altered in Preeclampsia?
}

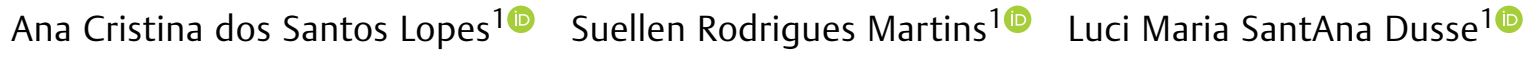 \\ Melina de Barros Pinheiro ${ }^{20}$ Patrícia Nessralla Alpoim ${ }^{10}$
}

1 Department of Clinical and Toxicological Analysis, Faculdade de Farmácia, Universidade Federal de Minas Gerais, Belo Horizonte, MG, Brazil

2 Universidade Federal de São Joao del-Rei, Divinópolis, MG, Brazil

Rev Bras Ginecol Obstet 2021;43(3):232-234.

\section{Dear Editor,}

Our research group has been studying preeclampsia (PE) for over a decade aiming to detect possible blood biomarkers of hemostasis, ${ }^{1-5}$ inflammation, ${ }^{6,7}$ and endothelial dysfunction $^{8-10}$ that could be useful for the diagnosis of PE. Until today, only the onset of hypertension $(\geq 140 \mathrm{mmHg}$ systolic or $\geq 90 \mathrm{mmHg}$ diastolic) on or after 20 weeks of gestation in association or not with proteinuria and/or evidences of multisystem impairment (such as renal, liver and neurological dysfunctions) is an acceptable criterion to establish the diagnosis of this gestational disease. ${ }^{11}$ It is important to emphasize that PE affects between 2 and $8 \%$ of all pregnancies worldwide, an early diagnosis of the disease, before the occurrence of systematic impairment, is still not available, which motivates our arduous search for laboratory markers of PE. ${ }^{12,13}$

Endocan is a biochemical marker of endothelial dysfunction that is potentially associated with immunoinflammatory response. ${ }^{14,15}$ Previous data of our group showed that endothelial dysfunction and inflammation are important features in PE. ${ }^{6,8,9}$ Aiming to determine if endocan plasma levels could be useful for determining PE predisposition and/ or development, we investigate its levels in preeclamptic and normotensive pregnant women from the southeastern state of Minas Gerais, Brazil.

Our case-control study included 80 Brazilian pregnant women, 40 with severe PE ( $\geq 160 \mathrm{mmHg}$ systolic or $>110$ $\mathrm{mmHg}$ diastolic pressure) and 40 normotensive pregnant women (controls). Endocan levels were investigated by enzyme-linked immunosorbent assay (ELISA). The statistical analysis was performed using IBM SPSS Statistics for Windows, version 19.0 (IBM Corp., Armonk, NY, USA). Data
Address for correspondence Patrícia Nessralla Alpoim, Room 4104B3, 6627, Antônio Carlos Ave, Belo Horizonte, MG, 31270-901, Brazil (e-mail: patnessralla@yahoo.com.br).

normality was tested by the Shapiro-Wilk test. The differences in endocan levels between the PE and normotensive groups were assessed by the Mann-Whitney test. P-values $<0.05$ were considered statistically significant.

Surprisingly, no significant difference was observed comparing endocan plasma levels between PE $(0.388 \mathrm{ng} / \mathrm{mL}$ [0.346-0.516]) and normotensive pregnant women (0.393 $\mathrm{ng} / \mathrm{mL}[0.321-0.623])(p=0.870)$. We classified PE by the onset time of clinical symptoms, such as early ( $<34$ weeks) or late PE ( $\geq 34$ weeks), ${ }^{3}$ and compared endocan levels in these groups. Again, no significant difference was observed for early $(0.385 \mathrm{ng} / \mathrm{mL}$ [0.311-0.459]) and late PE (0.407 ng/ $\mathrm{mL}$ [0.313-0.500]) and normotensive pregnant women $(0.393 \mathrm{ng} / \mathrm{mL}[0.244-0.542])(p=0.851)$.

A review of the literature showed eight studies that investigated endocan in women with PE. ${ }^{16-23}$ According to our data, two studies showed no significant difference between endocan levels in preeclamptic versus normotensive pregnancy. ${ }^{16,18}$ However, five studies revealed increased levels in women with PE versus normotensive pregnancy ${ }^{17,19,21-23}$ and two studies showed that endocan protein in the placenta tissue is upregulated in $\mathrm{PE}^{18,20}$ suggesting its involvement in the pathogenesis of PE. Of note, among the studies that found a positive association between endocan levels and PE development, one was also conducted in Brazil. ${ }^{22}$ It is well-established that high levels of tumor necrosis factor- $\alpha$ (TNF- $\alpha$ ) and vascular endothelial growth factor (VEGF) are able to stimulate the expression of endocan. ${ }^{24,25}$ It should be highlighted that the women with PE of the present study showed no previous increase of TNF- $\alpha$ plasma levels ${ }^{3}$ and lower VEGF levels ${ }^{26}$ comparing with normotensive pregnant. These data could justify why received

August 21, 2020

accepted

February 4, 2021
DOI https://doi.org/ $10.1055 / \mathrm{s}-0041-1728661$ ISSN 0100-7203.
(C) 2021. Federação Brasileira de Ginecologia e Obstetrícia. All rights reserved.

This is an open access article published by Thieme under the terms of the Creative Commons Attribution License, permitting unrestricted use, distribution, and reproduction so long as the original work is properly cited. (https://creativecommons.org/licenses/by/4.0/)

Thieme Revinter Publicações Ltda., Rua do Matoso 170, Rio de Janeiro, RJ, CEP 20270-135, Brazil 
endocan levels were not elevated in the women with PE studied.

Interestingly, Chang et al. ${ }^{18}$ related that, although plasma levels of endocan do not correlate with the occurrence of PE, an increased expression of mRNA and endocan were found in the placenta of women with PE, it could suggest that endocan is related to PE pathophysiology, but only in the microenvironment of the placenta, not reflecting the placental changes in plasma. Therefore, our research group aims to evaluate the expression of endocan in the placenta, in addition to repeating the plasma analyzes in a larger sample, to confirm that the results are in fact not significant in the population studied.

In conclusion, our findings showed no association between endocan levels and PE occurrence in Brazilian pregnant women. The role of endocan as endothelial function biomarker is unquestionable. Since endothelial dysfunction and systematic inflammatory response are among the key pathophysiological mechanisms for PE, future studies are required to investigate how endocan is involved in the occurrence of PE.

\section{Funding}

The authors thank the staff of the hospitals and the women who participated in the present study. Dusse L. M. S. is grateful for the CNPq fellowship. The present study was supported by FAPEMIG under grant number 0076416; and CNPq/Brazil under grant number 404353/2016-9.

\section{Conflict to Interests}

The authors have no conflict of interests to declare.

\section{References}

1 Dusse L, Godoi L, Kazmi RS, Alpoim P, Petterson J, Lwaleed BA, et al. Sources of thrombomodulin in pre-eclampsia: renal dysfunction or endothelial damage? Semin Thromb Hemost. 2011;37 (02):153-157. Doi: $10.1055 / \mathrm{s}-0030-1270343$

2 Dusse LM, Alpoim PN, Lwaleed BA, de Sousa LP, Carvalho Md, Gomes $\mathrm{KB}$. Is there a link between endothelial dysfunction, coagulation activation and nitric oxide synthesis in preeclampsia? Clin Chim Acta. 2013;415:226-229. Doi: 10.1016/j.cca.2012.10.006

3 Pinheiro MB, Carvalho MG, Martins-Filho OA, Freitas LG, Godoi LC, Alpoim PN, et al. Severe preeclampsia: are hemostatic and inflammatory parameters associated? Clin Chim Acta. 2014; 427:65-70. Doi: 10.1016/j.cca.2013.09.050

4 Alpoim PN, Godoi LC, Freitas LG, Pinheiro MdeB, Gomes KB, Dusse LM. Is intraplatelet cGMP jeopardized to inhibit platelet activation in severe preeclampsia? Blood Coagul Fibrinolysis. 2015;26(06): 711-713. Doi: 10.1097/MBC.0000000000000226

5 Lucena FC, Lage EM, Teixeira PG, Barbosa AS, Diniz R, Lwaleed B, et al. Longitudinal assessment of D-dimer and plasminogen activator inhibitor type-1 plasma levels in pregnant women with risk factors for preeclampsia. Hypertens Pregnancy. 2019; 38(01):58-63. Doi: 10.1080/10641955.2019.1577435

6 Pinheiro MB, Martins-Filho OA, Mota AP, Alpoim PN, Godoi LC, Silveira ACO, et al. Severe preeclampsia goes along with a cytokine network disturbance towards a systemic inflammatory state. Cytokine. 2013;62(01):165-173. Doi: 10.1016/j.cyto.2013.02.027

7 Perucci LO, Gomes KB, Freitas LG, Godoi LC, Alpoim PN, Pinheiro $\mathrm{MB}$, et al. Soluble endoglin, transforming growth factor-Beta 1 and soluble tumor necrosis factor alpha receptors in different clinical manifestations of preeclampsia. PLoS One. 2014;9(05): e97632. Doi: 10.1371/journal.pone.0097632

8 Alpoim PN, Godoi LC, Freitas LG, Gomes KB, Dusse LM. Assessment of L-arginine asymmetric 1 dimethyl (ADMA) in early-onset and late-onset (severe) preeclampsia. Nitric Oxide. 2013;33:81-82. Doi: 10.1016/j.niox.2013.07.006

9 Alpoim PN, Gomes KB, Pinheiro MdeB, Godoi LC, Jardim LL, Muniz LG, et al. Polymorphisms in endothelial nitric oxide synthase gene in early and late severe preeclampsia. Nitric Oxide. 2014; 42:19-23. Doi: 10.1016/j.niox.2014.07.006

10 Alpoim PN, Perucci LO, Godoi LC, Goulart COL, Dusse LMS. Oxidative stress markers and thrombomodulin plasma levels in women with early and late severe preeclampsia. Clin Chim Acta. 2018;483:234-238. Doi: 10.1016/j.cca.2018.04.039

11 American College of Obstetricians and Gynecologists Task Force on Hypertension in Pregnancy. Hypertension in pregnancy. Report of the American College of Obstetricians and Gynecologists' Task Force on Hypertension in Pregnancy. Obstet Gynecol. 2013;122(05): 1122-1131. Doi: 10.1097/01.AOG.0000437382.03963.88

12 Khan KS, Wojdyla D, Say L, Gülmezoglu AM, Van Look PF. WHO analysis of causes of maternal death: a systematic review. Lancet. 2006;367(9516):1066-1074. Doi: 10.1016/S0140-6736(06) 68397-9

13 Duley L. The global impact of pre-eclampsia and eclampsia. Semin Perinatol. 2009;33(03):130-137. Doi: 10.1053/j.semperi.2009.02.010

14 Kali A, Shetty KS. Endocan: a novel circulating proteoglycan. Indian J Pharmacol. 2014;46(06):579-583. Doi: 10.4103/02537613.144891

15 Balta S, Mikhailidis DP, Demirkol S, Ozturk C, Celik T, Iyisoy A. Endocan: A novel inflammatory indicator in cardiovascular disease? Atherosclerosis. 2015;243(01):339-343. Doi: 10.1016/j. atherosclerosis.2015.09.030

16 Yuksel MA, Tuten A, Oncul M, Acikgoz AS, Yuksel IT, Toprak MS, et al. Serum endocan concentration in women with pre-eclampsia. Arch Gynecol Obstet. 2015;292(01):69-73. Doi: 10.1007/ s00404-014-3605-X

17 Cakmak M, Yilmaz H, Bağlar E, Darcin T, Inan O, Aktas A, et al. Serum levels of endocan correlate with the presence and severity of pre-eclampsia. Clin Exp Hypertens. 2016;38(02):137-142. Doi: 10.3109/10641963.2015.1060993

18 Chang X, Bian Y, Wu Y, Huang Y, Wang K, Duan T. Endocan of the maternal placenta tissue is increased in pre-eclampsia. Int J Clin Exp Pathol. 2015;8(11):14733-14740

19 Hentschke MR, Lucas LS, Mistry HD, Pinheiro da Costa BE, Poli-deFigueiredo CE. Endocan-1 concentrations in maternal and fetal plasma and placentae in pre-eclampsia in the third trimester of pregnancy. Cytokine. 2015;74(01):152-156. Doi: 10.1016/j. cyto.2015.04.013

20 Chew BS, Ghazali R, Othman H, Ismail NAM, Othman AS, Laim NMST, et al. Endocan expression in placenta of women with hypertension. J Obstet Gynaecol Res. 2019;45(02):345-351. Doi: $10.1111 /$ jog. 13836

21 Adekola H, Romero R, Chaemsaithong P, Korzeniweski SJ, Dong Z, Yeo L, et al. Endocan, a putative endothelial cell marker, is elevated in preeclampsia, decreased in acute pyelonephritis, and unchanged in other obstetrical syndromes. J Matern Fetal Neonatal Med. 2015;28(14):1621-1632. Doi: 10.3109/ 14767058.2014.964676

22 Hentschke MR, da Cunha Filho EV, Vieira MC, Paula LG, Mistry HD, Costa BEP, et al. Negative correlation between placental growth factor and endocan-1 in women with preeclampsia. Rev Bras Ginecol Obstet. 2018;40(10):593-598. Doi: 10.1055/s-0038-1670713

23 Schuitemaker JHN, Cremers TIFH, Van Pampus MG, Scherjon SA, Faas MM. Changes in endothelial cell specific molecule 1 plasma levels during preeclamptic pregnancies compared to healthy pregnancies. Pregnancy Hypertens. 2018;12:58-64. Doi: 10.1016/j.preghy.2018.02.012 
24 Delehedde M, Devenyns L, Maurage CA, Vivès RR. Endocan in cancers: a lesson from a circulating dermatan sulfate proteoglycan. Int J Cell Biol. 2013;2013:705027. Doi: 10.1155/2013/705027

25 Shin JW, Huggenberger R, Detmar M. Transcriptional profiling of VEGF-A and VEGF-C target genes in lymphatic endothelium reveals endothelial-specific molecule- 1 as a novel mediator of lymphangiogenesis. Blood. 2008;112(06):2318-2326. Doi: 10.1182/blood-2008-05-156331

26 Rios DRA, Alpoim PN, Godoi LC, Perucci LO, Sousa LR, Gomes KB, et al. Increased levels of SENG and SVCAM- 1 and decreased levels of VEGF in severe preeclampsia. Am J Hypertens. 2016;29(11): 1307-1310. Doi: 10.1093/ajh/hpv170 